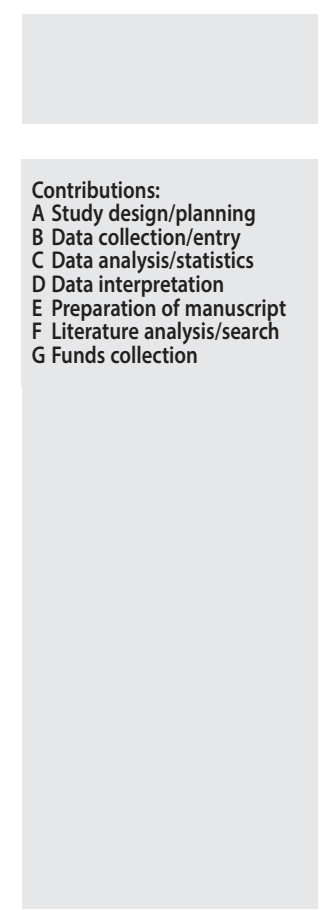

\title{
VESTIBULAR SYMPTOMS AFTER COCHLEAR IMPLANTATION: CLINICAL OVERVIEW AFTER A 2-YEAR FOLLOW-UP
}

\section{Magdalena Sosna-Duranowska ${ }^{1, A-F}$, Grażyna Tacikowska ${ }^{1, A-B}$, Elżbieta Gos ${ }^{2, C-D}$, Piotr H. Skarżyński ${ }^{3,4,5,6, E}$, Henryk Skarżyński ${ }^{6, B, E}$}
${ }^{1}$ Department of Otoneurology, Institute of Physiology and Pathology of Hearing, Poland
2 Department of Teleaudiology and Screening, Institute of Physiology and Pathology of Hearing, Poland
${ }^{3}$ Department of Teleaudiology and Screening, Institute of Physiology and
Pathology of Hearing, Poland
${ }^{4}$ Institute of Sensory Organs, Poland
${ }^{5}$ Heart Failure and Cardiac Rehabilitation Department, Second Faculty of the Medical University of Warsaw, Poland
${ }^{6}$ Otorhinolaryngosurgery Clinic, Institute of Physiology and Pathology of Hearing, Warsaw, Poland

Corresponding author: Magdalena Sosna-Duranowska; Department of Otoneurology, Institute of Physiology and Pathology of Hearing, Mokra 17, 05830, Nadarzyn, Poland; email: m.sosna@ifps.org.pl; Phone: +48 223118129

\section{Abstract}

Background: Vestibular symptoms and balance disorders are still common complaints reported by the patients after cochlear implantation (CI). Much research has been devoted to assess dizzy patients after cochlear implantation using both self-prepared questionnaires as well as validated life-quality scales. From this work, various approaches to classifying symptoms according to their onset and duration have been recommended.

Material and methods: We studied 101 patients after round window approach (RWA) cochlear implantation giving them a self-prepared questionnaire asking them to list their major vestibular complaints formulated according to the consensus document of the Barany Society Committee for the classification of vestibular disorders. Those with persistent symptoms (both postoperatively and existing preoperatively) also filled in a DHI questionnaire. Additionally, cVEMP, oVEMP, caloric, and vHIT tests were performed before and after the CI procedure.

Results: The 101 patients were divided into four groups: with early symptoms $(n=25)$, with late symptoms $(n=2)$, with preoperative symptoms $(n=13)$, and with no symptoms $(n=61)$. Among the patients with early symptoms, 15 reported spontaneous vertigo attack, 6 only unsteadiness and/or lateropulsion, and 4 had other symptoms such as orthostatic vertigo, positional vertigo, visual tilt, and head-motion vertigo.

Conclusions: Close to $40 \%$ of the CI recipients suffered from vestibular complaints, either in the postoperative period or from already existing preoperative symptoms. The vast majority of postoperative complaints were transient and only rare cases (with preexisting inner ear pathologies and/or comorbidities) evolved into persistent dysfunction.

Key words: benign paroxysmal positional vertigo • cochlear implantation• round window approach• vestibular symptoms• vestibular damage

\section{OBJAWY PRZEDSIONKOWE PO IMPLANTACJI ŚLIMAKOWEJ: PRZEGLĄD KLINICZNY OBEJMUJĄCY OKRES DWULETNIEJ OBSERWACJI}

\section{Streszczenie}

Wstęp: Objawy przedsionkowe są wciąż najczęściej zgłaszanymi skargami pooperacyjnymi wśród pacjentów po implantacji ślimakowej. Wiele badań poświęcono ich ocenie stosując zarówno samodzielnie przygotowane kwestionariusze objawowe, jak i zwalidowane ankiety jakości życia. Na podstawie zebranych wyników zalecano różne strategie klasyfikowania objawów przedsionkowych u takich pacjentów w zależności od ich początku i czasu trwania.

Materiał i metody: 101 pacjentów po implantacji ślimakowej z dostępu przez okienko okrągłe (RWA) otrzymało samodzielnie przygotowany kwestionariusz dotyczący objawów przedsionkowych wg konsensusu przygotowanego przez Towarzystwo Barany’ego. Dodatkowo, pacjenci z przetrwałymi objawami (zarówno istniejącymi już przedoperacyjnie, jak i pojawiającymi się pooperacyjnie) wypełnili ankietę DHI. Badania cVEMP,oVEMP, testy kaloryczne i vHIT były wykonywane przed oraz 1-3miesięcy (cVEMP,oVEMP) i 4-6miesięcy (próby kaloryczne, vHIT) po wszczepieniu implantu ślimakowego.

Wyniki: Pacjentów podzielono na cztery grupy: z wczesnymi objawami $(n=25 ; 24.75 \%)$, późnymi objawami ( $n=2 ; 1.98 \%)$, objawami występującymi przedoperacyjnie $(n=13,12.75 \%)$ oraz bezobjawowych $(n=61 ; 60.4 \%)$. Wśród pacjentów z wczesnymi objawami: 15 zgłosiło samoistne vertigo (14.85\%), 6 (5.94\%)- tylko uczucie ściągania/niepewności, 4 (3.96\%) - inne objawy przedsionkowe jak vertigo ortostatyczne, ze zmiany położenia ciała, związane z ruchami głową, wrażenie przechylania obrazu. 
Wnioski: $39.6 \%$ z badanych użytkowników implantów ślimakowych zgłaszało objawy przedsionkowe, włączając w to zarówno te występujące pooperacyjnie, jak i te istniejące wcześniej. Zdecydowana większość objawów była przejściowa i tylko w niezwykle rzadkich przypadkach (wcześniej istniejące patologie ucha wewnętrznego i/oraz choroby współistniejące) miała charakter przetrwały.

Słowa kluczowe: łagodne napadowe położeniowe zawroty głowy • implantacja ślimakowa • dostęp przez okienko okrągłe • objawy przedsionkowe • uszkodzenie obwodowego narządu przedsionkowego

\section{Introduction}

Vestibular symptoms and balance disorders remain common complaints reported by patients after receiving a cochlear implant (CI) [1-3].

There are multiple mechanisms that may explain vestibular symptoms among CI recipients: labyrinthine irritation and inflammation from foreign bodies (blood, bone dust, electrodes), a reaction involving serous labyrinthitis [1,3], loss of intraoperative perilymph [4], and finally electrode insertion trauma involving direct damage to the vestibular hair cells (or their necrosis due to mixing of endolymph and perilymph if the basilar membrane is ruptured) [5-7]. Moreover, there are cases where otoconia have been apparently dislodged as a result of intraoperative drilling or spread of electric current during CI activation, with consequent benign paroxysmal positional vertigo [8]. In delayed period, fibrosis or obliteration of the inner ear or endolymphatic hydrops caused by the disturbance of inner ear fluid homeostasis may appear[6], and sometimes electric co-stimulation of vestibular fibers [9] may cause vestibular symptoms.

Vestibular function can be measured with a wide range of tests, such as cervical Vestibular Evoked Myogenic Potentials (cVEMP), ocular Vestibular Evoked Myogenic Potentials (oVEMP), caloric test, rotatory chair, or video Head Impulse Test (vHIT). In the case of positional vertigo, a Hallpike or roll test can be conducted. None of these necessarily provides a full correlation with the vestibular symptoms described by the patient, or with their intensity and persistence [10]. Even if postoperative unilateral vestibular damage does occur, because of central nervous compensation mechanisms it rarely results in persistent or long-lasting vestibular symptoms. Benign paroxysmal positional vertigo may be overlooked if the tests are not performed during the attacks, since the condition may resolve spontaneously [11]. Finally, many central nervous pathologies and other comorbidities may strongly affect vestibular symptoms or cause balance disorders even when the peripheral vestibular organ is intact.

Much research has been devoted to assessing dizzy patients after cochlear implantation using both self-prepared questionnaires $[1,3,12-13]$ or validated life-quality scales. Various approaches to classifying the symptoms according to their onset and duration have been recommended. All of them apply general descriptions of vestibular symptoms such as dizziness, vertigo, lightheadedness, and unsteadiness. Because of the frequent occurrence of vestibular symptoms preoperatively and the wide variety of vestibular symptoms, all these approaches may not describe the situation well, and may even overlook possible changes in the vestibular system after a CI. For instance, the appearance of oscillopsia after a CI in a patient already suffering from postural unsteadiness may indicate damage to the second vestibulum. Postoperative vertigo lasting a couple of days, reported by patients with Meniere disease, may be a symptom of vestibular function loss.

The aim of this study was to assess the incidence, duration, and type of vestibular symptoms after cochlear implantation using the Barany Society classification [14].

\section{Materials and methods}

The patients received a prospectively self-prepared questionnaire [15] asking them to list their major vestibular complaints formulated according to the consensus document of the Barany Society Committee for the classification of vestibular disorders. They were asked to provide four ratings: preoperatively, for 1-3 months, 6-9 months, and 2-3 years after the CI procedure. The symptoms were categorized as: spontaneous vertigo (external or internal, spinning and non-spinning), spontaneous dizziness, positional vertigo/dizziness, head-motion vertigo/dizziness, visuallyinduced vertigo/dizziness, sound-induced vertigo/dizziness, Valsalva-induced vertigo/dizziness, orthostatic vertigo/dizziness, oscillopsia, visual lag, visual tilt, movement-induced blur, unsteadiness, directional pulsion, balance-related nearfalls, and balance-related falls. The respondents were also asked about the onset, duration, and form of the symptoms (attacks vs permanent). The symptoms were divided into: early (within the first 4 weeks after cochlear implantation) and delayed ( $>4$ weeks after cochlear implantation but within 2 years). Both early and delayed symptoms were further divided into: transient (lasting up to 4 weeks, resolved spontaneously), protracted (lasting 1-6months or demanding an otoneurological consultation with therapeutical steps), and persistent ( $>6$ months despite appropriate treatment). Patients who reported vestibular symptoms both in the early and delayed period were categorized as early and the duration of the symptoms was taken to be the sum of the periods. Additionally, patients with permanent or recurrent symptoms filled in a DHI questionnaire [16]. All patients participated in a research program involving: preoperative measurement of vestibular function (with cVEMP, oVEMP, vHIT, and caloric test); 1-3 months postoperative tests (cVEMP, oVEMP), and 4-6 months postoperative tests (caloric test, vHIT). A Hallpike and roll test were conducted if positional vertigo was reported. The study was approved by the institution's ethics committee $(\mathrm{KB} / 15 / 2014)$ and all patients signed an informed consent form before taking part. In those with permanent symptoms (existing preoperatively or not) and DHI scores $>10$, their final diagnosis was used. Additionally, the diagnosis of the patients with 'new' vestibular symptoms was presented if accessible.

The vestibular symptoms were divided into four groups:

1) One episode of vertigo/diziness attack lasting at least 12 hours.

2) Recurrent spontaneous vertigo/diziness attacks. The longest episode was taken into consideration and was assessed to be: 
a) a few seconds to a few minutes

b) $20 \mathrm{~min}$ to 12 hours

c) $>12$ hours.

3) Unsteadiness, directional pulsion while sitting, standing, or walking, near-fall related symptoms.

4) Permanent or recurrent symptoms including (but excluding symptoms during vertigo/diziness attacks):

a) Visual lag or movement-induced blur

b) Positional vertigo/dizziness

c) Visual-induced vertigo/dizziness

d) Valsalva-induced vertigo/dizziness

e) Sound-induced vertigo/dizziness (including vestibular symptoms limited or strongly intensified by the active CI)

f) Oscillopsia

g) Visual tilt

h) Balance-related falls

i) Orthostatic vertigo/dizziness.

Symptoms were classified as new if:

- no symptoms before cochlear implantation occurred, but were reported afterwards

- the symptoms which appeared were from a new category/subcategory

- there had been vestibular symptoms in the past, but not in the 3 years before the cochlear implantation and they were reported again after CI procedure.

Symptoms were classified as pre-existing preoperative if: - the symptoms were present both preoperatively and postoperatively and were within the same category (were the continuation of preoperative symptoms).

No symptoms were judged if:

- no symptoms were reported preoperatively or postoperatively

- there were vestibular symptoms preoperatively but not postoperatively within at least a 2 -year follow-up period

- the patient reported some mild symptoms directly after the operation (dizziness, unsteadiness, but not vertigo) lasting $<12 \mathrm{~h}$

- the symptoms were mild permanent with DHI $\leq 10$ (from the categories 3 and 4, but no recurring vertigo attacks).

We determined whether there were any predisposing factors for vestibular disorders: age at implantation, gender, duration of hearing loss, bilateral implantation.

Of 149 candidates enrolled in the study, 48 were excluded because of: a) neurodegenerative disease that developed after implantation which strongly influenced balance $(n=1)$; b) schizophrenia without satisfactory remission $(n=1)$; c) patient's death $(n=1)$; d) head trauma in the postoperative period $(n=1)$; e) reimplantation necessary due to an abscess near the implant well $(n=1)$; f) reimplantation necessary due to failure of the CI processor $(n=1)$; g) not fully following the protocol $(n=27)$; h) too short a followup at the time of the summary $(n=15)$.

Altogether, the symptoms of 101 patients who had been implanted with the round window approach (RWA) were analyzed and among them 10 had received a subsequent second implant. Cochlear implantation was conducted according to six steps: 1) antrotomy, 2) posterior tympanotomy with visualization of the round window niche, 3 ) micropuncture of the round window, 4) insertion of the electrode into scala tympani through the round window, 5) electrode fixation in the round window niche with fibrin glue (with round window membrane left partially uncovered), 6) fixation of the device in the bone [17-18]. The procedures were performed by five different otosurgeons.

A chi-square test for independence was used to test differences between the three groups of patients in terms of one categorical variable (gender). A Kruskal-Wallis test was conducted to compare levels of quantitative variables (age, duration of hearing loss) between the groups. Statistical significance was specified as a $p$-value less than 0.05 . Data analysis was carried out using IBM SPSS Statistics v. 24.

\section{Results}

The study group consisted of 101 patients (54 women, 47 men) aged from 10.4 to 80.2 years old $(\mathrm{M}=44.8$; $\mathrm{SD}=18.9)$. Patients were divided into four groups: patients with early symptoms $(n=25 ; 24.8 \%)$, with late symptoms ( $n=2 ; 2 \%)$, with preoperative symptoms $(n=13,12.9 \%)$, and with no symptoms $(n=61,60.4 \%)$.

The group with "no symptoms" consisted of 54 patients totally without symptoms $(88.5 \%) ; 6$ (9.8\%) with mild symptoms and DHI $\leq 10$ (unsteadiness in 3 cases, visualinduced vertigo in 1 , head-motion vertigo in 1 , soundinduced vertigo in 1$)$; and $1(1.6 \%)$ with dizziness lasting only a few hours directly after cochlear implantation.

In the group with early symptoms, 15/25 (60\%) had complaints that spontaneously resolved within one month, $8 / 25$ (32\%) were protracted and lasted more than one month or required otoneurological interventions, and $2 / 25$ presented persistent symptoms. There were $21 / 25$ (84\%) who developed symptoms within the first week postoperatively, $3 / 25(12 \%)$ during the second week, and $1 / 25(4 \%)$ at the end of the first postoperative month. There were 18/25 (72\%) who had completely new symptoms and 7/25 (28\%) where there was a change in their character.

Among the CI recipients with early symptoms: 6 reported spontaneous vertigo, unsteadiness, and lateropulsion; 3 - spontaneous vertigo, unsteadiness, lateropulsion, positional vertigo; 1 - spontaneous vertigo, unsteadiness, balance-related near-falls, head-motion vertigo, positional vertigo; 1 - unsteadiness, lateropulsion, head-motion vertigo, positional vertigo; 1 - orthostatic vertigo; 1 - visual tilt; 1 - positional vertigo; 6 - unsteadiness, lateropulsion; 3 - spontaneous vertigo, head-motion vertigo, visualinduced vertigo, unsteadiness, lateropulsion, balance-related near-falls; 1 - spontaneous vertigo, head-motion vertigo, positional vertigo, unsteadiness, lateropulsion; 1 - spontaneous vertigo, visual tilt, unsteadiness, lateropulsion, balance-related near-falls. To sum up, 15 reported spontaneous vertigo attacks with accompanying vestibular symptoms $(14.9 \%), 6(6.0 \%)$ had only unsteadiness and lateropulsion, and 4 (4.0\%) had other vestibular symptoms (from the 4 th group). 
Table 1. Patients with 'new' early and delayed symptoms

\begin{tabular}{|c|c|c|}
\hline Vestibular symptoms & Diagnosis & $\begin{array}{l}\text { Number } \\
\text { of patients }\end{array}$ \\
\hline $\begin{array}{l}\text { Spontaneous vertigo, unsteadiness, lateropulsion, } \\
\text { positional vertigo }(1,3,4 \mathrm{~b})\end{array}$ & BPPV (posterior semicircular canal) on the implanted side & 2 \\
\hline $\begin{array}{l}\text { Spontaneous vertigo, head-motion vertigo, } \\
\text { unsteadiness, positional vertigo, balance-related near } \\
\text { falls }(1,3,4 a, 4 b)\end{array}$ & $\begin{array}{l}\text { Unilateral vestibular damage on the implanted side } \\
\text { postoperatively, BPPV on the implanted side, persistent } \\
\text { postural perceptual dizziness (PPPD), vestibular migraine }\end{array}$ & 1 \\
\hline Spontaneous vertigo, unsteadiness, lateropulsion $(1,3)$ & $\begin{array}{c}\text { Delayed endolymphatic hydrops, bilateral vestibular } \\
\text { dysfunction preoperatively }\end{array}$ & 1 \\
\hline $\begin{array}{l}\text { Spontaneous vertigo, head-motion vertigo, } \\
\text { visual-induced vertigo, unsteadiness, lateropulsion, } \\
\text { balance-related near falls }(1,3,4 a, 4 c)\end{array}$ & $\begin{array}{l}\text { Unilateral vestibular damage on the implanted side } \\
\text { postoperatively, SSCD on the opposite side, superior and } \\
\text { posterior semicircular canal damage on the previously } \\
\text { implanted ear }\end{array}$ & 1 \\
\hline Unsteadiness, lateropulsion (3) & $\begin{array}{c}\text { Decompensation of preoperatively existing unilateral } \\
\text { vestibular damage }\end{array}$ & 1 \\
\hline $\begin{array}{l}\text { Spontaneous vertigo, unsteadiness, lateropulsion, } \\
\text { positional vertigo }(1,3,4 \mathrm{~b})\end{array}$ & $\begin{array}{l}\text { Partial vestibular damage on the implanted side } \\
\text { postoperatively }\end{array}$ & 1 \\
\hline $\begin{array}{l}\text { Spontaneous vertigo, head-motion vertigo, } \\
\text { unsteadiness, lateropulsion, visual-induced vertigo, } \\
\text { balance-related near falls }(1,3,4 \mathrm{c})\end{array}$ & $\begin{array}{l}\text { Autoimmune inner ear disease, partial damage on the } \\
\text { implanted side postoperatively }\end{array}$ & 1 \\
\hline Orthostatic vertigo (4i) & Vertigo of non-peripheral origin & 1 \\
\hline Visual tilt $(4 \mathrm{~g})$ & $\begin{array}{l}\text { Partial vestibular damage on the operated side } \\
\text { postoperatively }\end{array}$ & 1 \\
\hline Unsteadiness, lateropulsion (3) & $\begin{array}{c}\text { Bilateral vestibular damage preoperatively, } \\
\text { decompensation }\end{array}$ & 2 \\
\hline $\begin{array}{l}\text { Spontaneous vertigo, unsteadiness, lateropulsion, head- } \\
\text { motion vertigo, positional vertigo }(1,3,4 a)\end{array}$ & $\begin{array}{l}\text { Vestibular damage and BPPV on the operated side } \\
\text { postoperatively }\end{array}$ & 1 \\
\hline Spontaneous vertigo, unsteadiness, lateropulsion $(1,3)$ & $\begin{array}{c}\text { Partial vestibular damage on the operated side } \\
\text { postoperatively, Meniere disease on the operated side } \\
\text { - remission }\end{array}$ & 1 \\
\hline \multirow[t]{2}{*}{ Recurrent vertigo attack (2b) } & $\begin{array}{l}\text { Delayed Meniere disease, vestibular damage on the } \\
\text { implanted side }\end{array}$ & 1 \\
\hline & Unknown origin & 12 \\
\hline
\end{tabular}

In the two patients $(2.0 \%)$ with persistent vestibular symptoms, the following diagnoses were made: unilateral vestibular damage on the implanted side, BPPV on the implanted side, persistent postural perceptual dizziness (PPPD), vestibular migraine $(n=1$, DHI $=66)$; unilateral vestibular damage on the implanted side, SSCD on the opposite side, superior and posterior semicircular canal damage on the previously implanted ear $(n=1, D H I=60)$. Neither was asymptomatic before cochlear implantation.

In the group with late onset (delayed) symptoms, the reported symptoms were as follows: vertigo attacks (2b) - 1 , vertigo attacks, unsteadiness, positional vertigo, visual tilt, visual-induced vertigo $(2 \mathrm{a}, 3,4 \mathrm{~b}, 4 \mathrm{c}, 4 \mathrm{~g})-1$. All the delayed symptoms started within the first 6 months of cochlear implantation and no correlation with the time of implant activation was noted. Both of them were protracted but resolved spontaneously.

Positional vertigo was reported in 10 cases (10\%). However, BPPV was proven in 6 cases ( 2 cases already present preoperatively and in 4 cases postoperatively only). In all 4 patients, the posterior semicircular canal was affected on the operated side and all patients showed a good response to repositioning manoeuvers (Epley, Semont). However, the percentage of detected BPPV cases may have been a little underestimated, as the symptoms could have resolved spontaneously before the neurotological consultation, and in some cases could not be done directly after cochlear implantation due to strong vertigo and vegetative symptoms.

No cases of sound-evoked vertigo or vertigo limited to an active CI were observed.

A clinical overview of the patients with early and delayed symptoms is shown in Table 1 .

Among the patients with preoperative symptoms, DHI scores ranged from 4 to $56, \mathrm{M}=32.3$ ( $\mathrm{SD} \pm 21.4$ ). Their clinical characteristics are depicted in Table 2.

The results of our study confirm the variability of possible vestibular disorders among cochlear implant recipients. The correlation between the results of vestibular tests and reported symptoms is presented in Table 3. Only some of the symptomatic patients showed a reduction in vestibular tests. Interestingly, we observed also a reduction in cVEMP,oVEMP, and caloric tests in non-symptomatic patients.

There were only 2 patients with late symptoms, not enough to consider them as statistically significant. Therefore the late group was excluded from further calculations. The statistical analysis of all three groups is shown in Table 4 . 
Table 2. Vestibular symptoms and diagnosis of the patients with preoperatively existing symptoms

\begin{tabular}{|c|c|c|}
\hline Vestibular symptoms & Diagnosis & $\begin{array}{l}\text { Number } \\
\text { of patients }\end{array}$ \\
\hline $\begin{array}{l}\text { Unsteadiness, lateropulsion, positional vertigo, Valsalva- } \\
\text { induced vertigo }(3,4 b, 4 d)\end{array}$ & LVAS bilaterally, benign paroxysmal positional vertigo & 1 \\
\hline Unsteadiness, lateropulsion (3) & $\begin{array}{l}\text { Preoperative vestibular damage on the side to be } \\
\text { implanted }\end{array}$ & 1 \\
\hline Unsteadiness, lateropulsion, visual lag $(3,4 a)$ & $\begin{array}{l}\text { Preoperative vestibular damage on the side to be } \\
\text { implanted }\end{array}$ & 1 \\
\hline Vertigo attacks (2a) & Vestibular paroxysmia & 1 \\
\hline $\begin{array}{l}\text { Unsteadiness, lateropulsion, recurrent vertigo attack } \\
(2 \mathrm{~b}, 3)\end{array}$ & $\begin{array}{c}\begin{array}{c}\text { Meniere disease and vestibular damage on the side to be } \\
\text { implanted }\end{array}\end{array}$ & 2 \\
\hline Recurrent vertigo attack, unsteadiness $(2 \mathrm{~b}, 3)$ & Meniere disease on the side to be implanted & 1 \\
\hline Unsteadiness, lateropulsion, balance-related near-falls (3) & $\begin{array}{l}\text { Bilateral hyporeflexia preoperatively, status post } \\
\text { meningitis }\end{array}$ & 1 \\
\hline $\begin{array}{l}\text { Unsteadiness, lateropulsion, Visual-induced vertigo, } \\
\text { visual tilt }(3,4 \mathrm{c}, 4 \mathrm{~g})\end{array}$ & Bilateral hyporeflexia preoperatively & 1 \\
\hline Unsteadiness, lateropulsion (3) & Bilateral hyporeflexia preoperatively & 1 \\
\hline Vertigo attacks, positional vertigo $(2 c, 4 b)$ & $\begin{array}{c}\text { Bilateral benign paroxysmal positional vertigo } \\
\text { preoperatively }\end{array}$ & 1 \\
\hline $\begin{array}{l}\text { Unsteadiness, lateropulsion, recurrent vertigo attack, } \\
\text { visual lag }(3,2 \mathrm{~b}, 4 \mathrm{a})\end{array}$ & $\begin{array}{l}\text { Possible Meniere disease with uncertain ear, partial } \\
\text { damage on the side to be implanted preoperatively }\end{array}$ & 1 \\
\hline Orthostatic vertigo (4i) & Vertigo of non-peripheral origin & 1 \\
\hline
\end{tabular}

Table 3. cVEMP, oVEMP, caloric tests, and vHIT results and their correlation with vestibular symptoms

\begin{tabular}{|c|c|c|c|c|c|}
\hline & & No symptoms & Early symptoms & $\begin{array}{c}\text { Delayed } \\
\text { symptoms }\end{array}$ & $\begin{array}{c}\text { Preoperatively } \\
\text { existing symptoms }\end{array}$ \\
\hline \multirow{3}{*}{$\begin{array}{l}\text { CVEMP } \\
n=97\end{array}$} & Maintained & $30 / 35(85.71 \%)$ & 7/12 (58.33\%) & - & $2 / 2(100 \%)$ \\
\hline & Loss & $5 / 35(14.29 \%)$ & $5 / 12$ (41.67\%) & $1(100 \%)$ & -- \\
\hline & Absent preoperatively & 23 & 13 & 1 & 10 \\
\hline \multirow{3}{*}{$\begin{array}{l}\text { OVEMP } \\
n=68\end{array}$} & Maintained & 14/19 (73.7\%) & 4/9 (44.44\%) & - & $2 / 2(100 \%)$ \\
\hline & Loss & 4/19 (21.05\%) & $5 / 9(55.5 \%)$ & $1(100 \%)$ & -- \\
\hline & Absent preoperatively & 16 & 12 & 1 & 8 \\
\hline \multirow{3}{*}{$\begin{array}{l}\text { Caloric test } \\
n=58\end{array}$} & Maintained & $20 / 23(86.96 \%)$ & 7/9 (77.78\%) & $1 / 2(50 \%)$ & 4/5 (80\%) \\
\hline & Loss & $3 / 23(13.04 \%)$ & $2 / 9$ (22.22\%) & $1 / 2(50 \%)$ & $1 / 5(20 \%)$ \\
\hline & Preoperative damage & 12 & 4 & - & 3 \\
\hline \multirow{3}{*}{$\begin{array}{l}\text { vHIT Lateral } \\
n=35\end{array}$} & Maintained & $15 / 15$ (100\%) & $4 / 5(80 \%)$ & $1 / 1(100 \%)$ & $3 / 3(100 \%)$ \\
\hline & Loss & $0 / 15(0 \%)$ & $1 / 5(20 \%)$ & - & - \\
\hline & Preoperative damage & 5 & 3 & - & 3 \\
\hline \multirow{3}{*}{$\begin{array}{l}\text { vHIT Anterior } \\
n=36\end{array}$} & Maintained & 15/15 (100\%) & $4 / 5(80 \%)$ & $1(100 \%)$ & $2 / 2(100 \%)$ \\
\hline & Loss & $0 / 15(0 \%)$ & $1 / 5(20 \%)$ & -- & -- \\
\hline & Preoperative damage & 6 & 4 & -- & 2 \\
\hline \multirow{3}{*}{$\begin{array}{l}\text { vHIT Posterior } \\
n=36\end{array}$} & Maintained & 15/15 (100\%) & $4 / 5(80 \%)$ & $1(100 \%)$ & $2 / 2(100 \%)$ \\
\hline & Loss & $0 / 15(0 \%)$ & $1 / 5(20 \%)$ & -- & -- \\
\hline & Preoperative damage & 6 & 3 & -- & 4 \\
\hline
\end{tabular}

There were no statistically significant differences between the four groups of patients in terms of sex. The highest mean age was in the patients with preoperative symptoms; it was lowest in the group with no symptoms and it reached statistical significance. No differences were observed between those with early and no vestibular symptoms in terms of age.
Duration of hearing loss was shortest in the group of patients with preoperative symptoms; the difference was statistically significant. Possibly, the factor that caused hearing loss and vestibular damage was stronger than the factor producing cochlear dysfunction alone, and it took less time from the onset of hearing loss until it reached a profound degree. 
Table 4. Sex, age, and duration of hearing loss in the patients

\begin{tabular}{|c|c|c|c|c|c|}
\hline & & Early & Preop & No & Test result \\
\hline \multirow{2}{*}{ Sex } & Women, $n(\%)$ & $13(25.0)$ & $10(19.2)$ & $29(55.8)$ & \multirow{2}{*}{$\begin{array}{l}\chi^{2}=3.71 \\
p=0.156\end{array}$} \\
\hline & Men, $n(\%)$ & $12(25.5)$ & $3(6.4)$ & $32(68.1)$ & \\
\hline \multirow{2}{*}{ Age } & Range & $10-75$ & $25-75$ & $11-80$ & \multirow{2}{*}{$\begin{array}{c}K-W=6.37 \\
p=0.041\end{array}$} \\
\hline & $M(S D)$ & 45.9 (19.3) & $56.5(15.2)$ & $42.0(18.9)$ & \\
\hline \multirow{2}{*}{$\begin{array}{l}\text { Hearing loss } \\
\text { duration (yr) }\end{array}$} & Range & $2.3-68.8$ & $1.1-55.7$ & $2.5-59.6$ & \multirow{2}{*}{$\begin{array}{c}K-W=6.75 \\
p=0.034\end{array}$} \\
\hline & $M(S D)$ & $27.0(16.6)$ & $15.3(16.3)$ & $21.7(12.1)$ & \\
\hline
\end{tabular}

Among the bilateral CI recipients, 3 of 10 (30\%) developed early symptoms and 7 (70\%) had no symptoms. There were 22 of 91 unilateral CI recipients (24.2\%) who reported early vestibular symptoms, 2 (2.2\%) late symptoms, 13/91 (14.3\%) preoperative symptoms, and 54/91 (59.3\%) no symptoms. Due to the small number of patients with bilateral CIs we did not conduct a statistical analysis of vestibular complaints between unilateral and bilateral cases.

\section{Discussion}

Vestibular symptoms after cochlear implantation is still a common finding in the postoperative period. Ito et al. [12] reported vestibular symptoms in 26 of 55 patients and divided them into: early transient (within the first 2 weeks, resolved spontaneously); early protracted (within the first 2 weeks, persistent); and delayed (more than 2 weeks after the CI). The majority of the patients belonged to the first group 15/26 (58\%), 9/26 (34\%) to the second, and the third were rare $2 / 26(8 \%)$. Zawawi et al. [13] classified the symptoms (56/112 - 50\%) as early (within the first days); delayed (after the first week, but within the first year after the CI); and delayed onset (more than one year after the $\mathrm{CI})$. Most of the dizzy patients belonged to the second group (45\%). Fina et al. [1] divided the symptoms (29/75,38.7\%) into: early (present within $24 \mathrm{~h}$ of implantation) and delayed onset (more than $24 \mathrm{~h}$ after implantation), pointing out the domination of the second group (25/29, 86.2\%). Kubo et al. [3] among all their patients with symptoms (46/94, $49 \%$ ) distinguished dizziness appearing and disappearing within one month after implantation (29/46, 63\%); permanent dizziness $(2 / 46,4.4 \%)$; and paroxysmal vertigo attacks appearing at least one month after implantation (15/46, 33\%). According to this classification, the majority of patients presented symptoms directly after implantation which spontaneously disappeared. To sum up, most reports show that vestibular symptoms are frequent and mostly appear within the first weeks after implantation. Long-lasting and persistent vestibular disorders are rare. That situation is in full agreement with our observations.

We expected that hearing preservation techniques (round window approach, soft electrode insertion, perioperative steroid administration) should be more protective of the vestibulum than standard techniques. In the literature the incidence of vestibular complaints after standard cochleostomy techniques ranges from 23 to $67 \%[1,3,12,19,20]$, and is slightly over $40 \%$ in most reports $[1,3,12,19]$. However, any comparison of the incidence of vestibular symptoms between patients implanted with RWA and cochleostomy has to be interpreted cautiously. Patients with low-frequency hearing loss have statistically better vestibular function, which may be lost after cochlear implantation [21]. If vestibular symptoms after a CI are generated, at least partly, by vestibular damage, even small traumatization of the vestibular organ may lead to symptoms. In the same way, in a profoundly deaf ear with non-functional residual hearing, even much more extensive vestibular trauma is less likely to evolve into vestibular symptoms. Of course, vestibular symptoms are multifactorial and may originate from additional causes.

We did not find that age was strongly correlated with the prevalence of vestibular symptoms after a CI procedure. Bilateral implantation did not seem to be a predisposing factor for postoperative symptoms either (at least in terms of their incidence, not their persistence).

The discrepancies between the results of vestibular tests and reported vestibular symptoms have been confirmed in other papers [22,23].

Until now, there has been no consensus regarding the necessity to make a vestibular evaluation of CI candidates, or look at possible vestibular contraindications for doing a CI procedure. The main threat of cochlear implantation is vestibular damage, with the worst scenario being profound bilateral vestibular damage. With bilateral vestibular damage many functions are affected: postural stability, visual stability during head movements, autonomic cardiovascular reaction of the lower part of the body while standing, cognitive abilities like spatial orientation, navigation abilities, and impairment in dual tasking [24]. Only $50 \%$ of patients with bilateral hypofunction profit from vestibular rehabilitation [24,25]. In addition, balance may get worse with age.

For these reasons, it would be reasonable to recommend special care and to consider the potential audiological benefits when deciding to give a second implant in the onlyfunctioning or better vestibulum.

The increasing interest in a vestibular prosthesis $[26,27]$ and vestibulocochlear implants [28] may in the future change our attitude towards bilateral loss of vestibular input. Preliminary reports on the artificial restoration of vestibuleocular reflexes are promising. However, as long as such efforts are still under development, and restricted to single clinics and small groups of patients $[26,27,28]$, we are obliged to avoid bilateral vestibular loss.

Another important issue that arises from our clinical overview is that, in cases of unilateral vestibular damage, comorbidities associated with coexisting neurological 
and psychiatric disorders limit the effectiveness of central compensation mechanisms [29]. These groups of patients should be carefully informed about the risk of postoperative vestibular damage and vestibular rehabilitation protocols should be introduced early on.

The main limitation of our study is that we focused on assessing vestibular symptoms qualitatively, and not according to their quantitative intensity. Additional long-term studies assessing the improvement or deterioration in patient quality of life are recommended.

\section{Conclusion}

To sum up, vestibular symptoms after cochlear implantation are still frequent findings in the postoperative period.
There were $40 \%$ of CI recipients who experienced vestibular complaints during our 2-year follow-up period, including both already existing and new vestibular complaints. The vestibular symptoms were mostly transient. Possible persistent problems, if any, were the result of an overlap of possible vestibulum traumatization, preexisting pathologies in the inner ear, and/or comorbidities. By becoming aware of the factors disturbing central compensation mechanisms after vestibular damage, and of the consequences of bilateral vestibular hypofunction, then persistent vestibular problems after CI may be largely reduced by introducing proper counseling and care in the postoperative period.

\section{References}

1. Fina M, Skinner M, Goebel JA, et al. Vestibular dysfunction after cochlear implantation. Otol Neurotol, 2003; 24:234-242.

2. Buchman CA, Joy J, Hodges A, et al. Vestibular effects of cochlear implantation. Laryngoscope, 2004; 114: 1-22.

3. Kubo T, Yamamoto K, Iwaki T, et al. Different forms of dizziness occurring after cochlear implant. Eur Arch Otorhinolaryngol, 2001; 258: 9-12.

4. Mangham CA. Effect of cochlear prostheses on vestibuloocular reflexes to rotation. Ann Otol Rhinol Laryngol Suppl, 1987; 12: $101-4$.

5. O'Leary MJ, Fayad J, House WF, Linthicum FH. Electrode insertion trauma in cochlear implantation. Ann Otol Rhinol Laryngol, 1991; 100: 695-9.

6. Tien H-C, Linthicum FH. Histopathologic changes in the vestibule after cochlear implantation. Otolaryngol Head Neck Surg, 2002; 127:260-64.

7. Eshragi AA, Lang DM, Roell J, Van de Water TR, Garnham C, Rodrigues H, Guardiola M, Gupta C, Mittal J. Mechanisms of programmed cell death signaling in hair cells and support cells post-electrode insertion trauma. Acta Otolaryngol, 2015; 135, $328-34$.

8. Viccaro M, Mancini P, La Gamma R et al. Positional vertigo and cochlear implantation. Otol Neurotol, 2007; 28: 764-7.

9. Coordes A, Basta D, Götze R et al. Sound-induced vertigo after cochlear implantation. Otol Neurotol, 2012; 33: 335-42.

10. Batuecas-Caletrio A, Klumpp M, Santacruz-Ruiz S, Benito Gonzalez F Gonzalez Sánchez E, Arriaga M. Vestibular function in cochlear implantation: correlating objectiveness and subjectiveness. Laryngoscope, 2015 Oct; 125(10): 2371-5.

11. Imai T, Ito M, Takeda N, Uno A, Matsunaga T, Sekine K, Kubo T. Natural course of the remission of vertigo in patients with benign paroxysmal positional vertigo. Neurology, 2005; 64(50): 920-1.

12. Ito J. Influence of the multichannel cochlear implant on vestibular function. Otolaryngol Head Neck Surg, 1998; 118(6): 900-2.

13. Zawawi F, Alobaid F, Leroux T, Zeitouni AG. Patients reported outcome post-cochlear implantation: how severe is their dizziness? J Otolaryngol Head Neck Surg, 2014; 43: 49.

14. Bisdorff A, Von Brevern M, Lempert T, Newman-Toker DE. Classification of vestibular symptoms: towards an international classification of vestibular disorders. J Vestib Res, 2009; 19: 1-13.

15. Gos E, Ratajczak A, Tacikowska G, Sosna M, Piłka A, Skarżyński PH. Kwestionariusz przesiewowy do oceny zawrotów głowy i zaburzeń równowagi. Nowa Audiofonologia, 2019; 8(2): 37-42.
16. Szostek-Rogula S, Zamysłowska-Szmytke E. Walidacja polskiej wersji kwestionariusza Dizziness Handicap Inventory. Otorynolaryngologia, 2018; 17(3): 105-11.

17. Skarzynski H, Lorens A, Piotrowska A, Skarzynski PH. Hearing preservation in partial deafness treatment. Med Sci Monit, 2010; 16: 555-62.

18. Skarzynski H, Lorens A, Piotrowska A, Anderson I. Preservation of low frequency hearing in partial deafness CI (PDCI) using the round window surgical approach. Acta Otolaryngol (Stockh), 2007; 127: 41-8.

19. Krause E, Louza JPR, Wechtenbruch J, Hempel J-M, Rader T, Gürkov R. Incidence and quality of vertigo symptoms after cochlear implantation. J Laryngol Otol, 2009; 123(3): 278-82.

20. Todt I, Basta D, Ernst A. Does the surgical approach in cochlear implantation influence the occurrence of postoperative vertigo? Otolaryngol Neck Surg, 2008; 138(1): 8-12.

21. Sosna M, Tacikowska G, Pietrasik K, Skarzynski H, Skarzynski PH. Vestibular status in partial deafness. Braz J Otorhinolaryngol, 2019 Nov 20; doi: 10.1016/j.bjorl.2019.09.012.

22. Meli A, Musameci Aud B, Tognocchi Aud S, Gaggi Aud R, Cristofari E. Vestibular function after cochlear implant surgery. Cochlear Implants Intl, 2016 May; 17(3): 151-7.

23. Melvin T-A, Della Santina C, Carey J, Migliaccio A. The effects of cochlear implantation on vestibular function. Otol Neurotol, 2009 Jan; 30(1): 87-94.

24. McCall A, Yates B. Compensation following bilateral vestibular damage. Front Neurol, 2011 Dec; 2: 88.

25. Gillespie MB, Minor LB. Prognosis in bilateral vestibular hypofunction. Laryngoscope, 1999; 109: 35-41.

26. Della Santina CC, Migliaccio AA, Hayden R et al. Current and future management of bilateral loss of vestibular sensation: an update of John Hopkins Multichannel Prosthesis Project. Cochlear Implants Intl, 2010 Sep; 11(Suppl 2): 2-11.

27. Rubinstein JT, Bierer S, Kaneko C, Ling L, Nie K, Oxford T et al. Implantation of the semicircular canals with preservation of hearing and rotational sensitivity: a vestibular neurostimulator suitable for clinical research. Otol Neurotol, 2012 Jul; 33(5): 789-96.

28. Perez Fornos A, Cavuscens S, Ranieri M, van de Berg R, Stokroos R, Kingma H, Guyot JP, Guinand N. The vestibular implant: a probe in orbit around the human balance system. J Vestib Res, 2017; 27(1): 51-61.

27. Whitney SL, Sparto PJ, Furman JM. Vestibular rehabilitation and factors that can affect outcome. Semin Neurol, 2020 Feb; 40(1): $165-72$. 